\title{
RECORDS OF PILCHARD SPAWNING IN THE ENGLISH CHANNEL
}

\author{
By P. G. Corbin, B.A. \\ Zoologist at the Plymouth Laboratory
}

(Text-fig. I)

The pilchard, Clupea pilchardus Walbaum, is known to spawn in summer in the southern North Sea in the neighbourhood of the Sandettié Bank(BuchananWollaston, I9I I Furnestin, I939 $a$, I945) and in the eastern English Channel off Beachy Head (Furnestin, I939 $a$, I945). Furnestin (I939 $b$, 1945) concludes from these records that spawning is in all probability continuous throughout the Channel from the southern North Sea to the Celtic Sea. There appear, however, to be no previous references to pilchard spawning in the central part of the English Channel. The following records from the area are of interest therefore, and provide confirmation of Furnestin's conclusion.

The station positions and numbers per haul are shown in Fig. I and Table I. The plankton samples were collected in 1947 and 1948 by $\frac{1}{2} \mathrm{hr}$. oblique hauls of the I m. stramin ring-net during cruises of the motor yacht Manihine, which was placed at the disposal of the British Museum (Natural History) through the generosity of Major H. W. Hall, M.C. In I948, a number of surface hauls with a medium silk townet were also taken by $\mathrm{Mr} \mathrm{M}$. H. W. Gall from his yacht Colleen. The writer is much indebted to the Trustees and Director of the British Museum for the opportunity of examining the Manihine collections, and to $\mathrm{Mr}$ Gall for the Colleen material.

A number of the Colleen stations $\left(C_{\mathrm{I}-\mathrm{I} 2}\right)$ were worked in the southern North Sea (see Gall, I949, fig. I3, p. 772). Pilchard eggs were taken at four of these stations; at the northern entrance to the Straits of Dover $\left(C_{9}\right.$, Sandettie Bank; $C$ IO, south-east of Goodwin Lightship) and to the north-east off the Belgian coast ( $C_{7}$, north-east of Bligh Bank; $C 8$, East Hinder Bank). None occurred at stations off the Norfolk coast $\left(C_{\mathrm{I}}, C_{3}\right.$ and $\left.C_{4}\right)$ or close in to the Belgian coast ( $C_{5}, C_{6}$ and $\left.C_{12}\right)$. The presence of pilchard eggs in the area of the East Hinder and Bligh Banks slightly extends to the north-east the known spawning area of the species in the southern North Sea.

The Manihine stations, all of which were worked in the English Channel, fall into two groups; one to the west, the other to the east of the Isle of Wight. The monthly means of the numbers of pilchard eggs from all stations (positive and negative) of the two groups are given on p. 94 . 


\section{Table I. Numbers of Pilchard EgGs, Etc. Per $\frac{1}{2}$ Hr. Oblique Haul of the I M. Stramin Net}

* denotes figurc obtained by subsampling.

$\begin{array}{lll}\text { Pilchard eggs } & \text { Sagitta setosa Muggiaea atlantica } \\ \text { (Mackerel eggs) (Sagitta elegans) (Muggiaea kochi) }\end{array}$

M.Y. Manihine
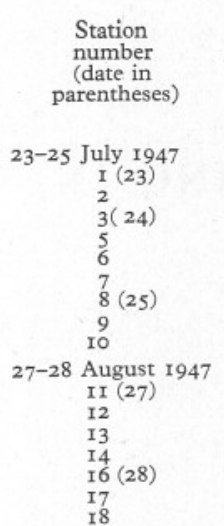

6-7 May 1948

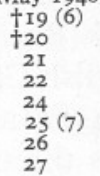

I5 June 1948

33

34

35
36
37

3-4 July I 948

40 (3)

$4 \mathrm{I}$

43 (4)

$43(4)$

44
45

3I August r 948

47
48

48
49
50

50

I5, 26 September 1948

$52(15)$
53
54
$57(26)$
58
59

CI (15. vii. 48 )

$\mathrm{C}_{3}$ (I6)

$C_{4}(19)$
$C_{5}(23)$

C6

C6
C8
(24)

C8 8 (25)

$C 9(25)$
$C$ Io (29)

$C 10$
$C$ I2 (29)

Cr2 (30)
CI3 (5. viii. 48 )
CI6 (14)

CI7 (Is)

C20 (20)

$\mathrm{C}_{2 \mathrm{I}}(2 \mathrm{I})$

C22 (24)

$\mathrm{C}_{23}$

C24 (6. ix. 48)

$\mathrm{C}_{25}$

$\mathrm{C}_{26}$ (9)

$\mathrm{C}_{27}$ (IO)
$\mathrm{C} 28$ (II) $50^{\circ} 29^{\prime}$ N., I $I^{\circ} 4 I^{\prime}$ W.

$50^{\circ} 20^{\prime}$ N., I $\mathrm{I}^{\circ} 43^{\prime}$ W.

$50^{\circ} 39^{\prime}$ N., $0^{\circ} 10^{\prime} \mathrm{W}$.

$20^{\circ}, g^{\prime} \mathrm{N}, 0^{\circ}, \mathrm{S}_{1}$

$50^{\circ} 09^{\prime} \mathrm{N}, 0^{\circ}$ O5' E.

$49^{\circ} 55^{\prime}$ N., N., $1^{\circ} 54^{\prime}$ W. W.

$49^{\circ} 55^{\prime}, \mathrm{N} ., \mathrm{I}^{\circ} 54^{\prime} \mathrm{W}$.

$50^{\circ} \mathrm{II}^{\prime}$ N., $\mathrm{I}^{\circ} 47^{\prime} \mathrm{W}$.

$50^{\circ} 26^{\prime}$ N., $0^{\circ} 25^{\prime}$ E.

$50^{\circ} 27^{\prime}$ N., $0^{\circ} 29^{\prime} \mathrm{E}$.

$50^{\circ} 20^{\prime}$ N., $0^{\circ} 37^{\prime}$ E.

$50^{\circ} \mathrm{I}_{3}, \mathrm{~N} ., \mathrm{O}^{\circ} 46^{\prime} \mathrm{E}$

$50^{\circ} 47, \mathrm{~N} ., 1 \circ 10^{\circ} \mathrm{E}$

$50^{\circ} \mathrm{O}^{\prime}$, N., I $\mathrm{I}^{\circ} 37^{\prime} \mathrm{E}$.

$50^{\circ} 39^{\prime}$ N., $0^{\circ} 39^{\prime} \mathrm{E}$.

$50^{\circ} 53^{\prime} \mathrm{N} ., 0^{\circ} 53^{\prime} \mathrm{E}$.

$50^{\circ} 47^{\prime}$ N., I I IO' E.

$50^{\circ} 38^{\prime}$ N., I ${ }^{\circ} 24^{\prime}$ E.

$50^{\circ} 3^{\prime}$ N., $0^{\circ} 46^{\prime} \mathrm{E}$.

$50^{\circ} 36^{\prime}$ N., $0^{\circ} 26^{\prime}$ E.

$50^{\circ} 36^{\prime}$ N., $0^{\circ} 26^{\prime} \mathrm{E}$.

$\begin{array}{ll}50^{\circ} 27^{\prime}, \mathrm{N} ., 0^{\circ} & 29^{\prime} \mathrm{E} . \\ 5 & \end{array}$

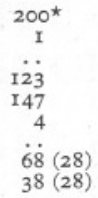

\begin{tabular}{|c|c|}
\hline $28(22)$ & $\ldots$ \\
\hline I (2) & . \\
\hline I4 (3) & . \\
\hline$\ldots$ & . \\
\hline . & $\cdots$ \\
\hline .. & $\cdots$ \\
\hline . & $\cdots$ \\
\hline$\cdots$ & $\cdots$ \\
\hline$\cdots$ & $\cdots$ \\
\hline 8 & . \\
\hline 5 & . \\
\hline . & $\cdots$ \\
\hline$\because$ & $\cdots$ \\
\hline 3 & 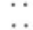 \\
\hline I & . \\
\hline
\end{tabular}

$50^{\circ} 40^{\prime}$ N., $0^{\circ} \mathrm{II}^{\prime} \mathrm{W}$.

$50^{\circ} 27^{\prime}$ N., $0^{\circ}$ I $8^{\prime} \mathrm{W}$.

$50^{\circ} \mathrm{I}^{\prime} \mathrm{N} ., 0^{\circ} \mathrm{O2}^{\prime} \mathrm{W}$.

$50^{\circ} 09^{\prime} \mathrm{N} ., 0^{\circ} 05^{\prime} \mathrm{W}$.

$50^{\circ} 00^{\prime}$ N., $0^{\circ} 00^{\prime}$

$50^{\circ} 29^{\prime}$ N., $1^{\circ} 42^{\prime}$ W.

$50^{\circ} 20^{\prime}$ N., I $\mathrm{I}^{\circ} 39^{\prime}, \mathrm{W}$.

$50^{\circ} \mathrm{Ir}^{\prime}$ N., $\mathrm{I}^{\circ} 45^{\prime} \mathrm{W}$.

$49^{\circ} 54, \mathrm{~N}, 2^{\circ}, \mathrm{W}, \mathrm{W}$

$49^{\circ} 54^{\prime}$ N., $\mathrm{I}^{\circ} 55^{\prime} \mathrm{W}$.

$49^{\circ} 55^{\prime}$ N., $2^{\circ} 08^{\prime} \mathrm{W}$.

$49^{\circ} 52^{\prime} \mathrm{N} ., 2^{\circ} 10^{\prime} \mathrm{W}$

$49^{\circ} 50^{\prime} \mathrm{N}^{\circ}, 2^{\circ} 08^{\prime} \mathrm{W}$

$49^{\circ} 49^{\prime}$, N., $2^{\circ} 28^{\prime}$ W.

$50^{\circ} 06^{\prime}$ N., $3^{\circ} 27^{\prime}$ W.

$50^{\circ} 00^{\prime}$ N., $3^{\circ} 16^{\prime}$ W

$49^{\circ} 5 \mathrm{I}^{\prime}, \mathrm{N} ., 3^{\circ}$. $7^{\prime}$, W.

50 3I N., I $25, \mathrm{E}$

$50^{\circ} 38^{\prime}, \mathrm{N} ., \mathrm{I}^{\circ} 26^{\prime}, \mathrm{E}$.

Yacht Colleen $\ddagger$

$52^{\circ} 28^{\prime}$ N., $1^{\circ} 47^{\prime}$, E.

$52^{\circ} 43^{\prime}$ N., $2^{\circ}$ I $8^{\prime}$ E.

$5 \mathrm{I}^{\circ} 5 \mathrm{I}^{\prime} \mathrm{N} ., 3^{\circ} 38^{\prime} \mathrm{E}$.

$51^{\circ} 55^{\prime}$ N., $3^{\circ} 29^{\prime}$. E.

$51^{\circ} 4^{\prime}$ N., $2^{\circ} 5^{\prime}$ E.

$5 \mathrm{I}^{\circ} 36^{\prime} \mathrm{N} ., 2^{\circ} 4 \mathrm{I}^{\prime} \mathrm{E}$.

$5 \mathrm{I}^{\circ} \mathrm{I}^{\prime} \mathrm{N}$., $\mathrm{I}^{\circ} 54^{\prime} \mathrm{E}$.

$5 \mathrm{I}^{\circ} \mathrm{II}^{\prime} \mathrm{N}$., $\mathrm{I}^{\circ} 39^{\prime} \mathrm{E}$.

$5 \mathrm{I}^{\circ} \mathrm{II}^{\prime} \mathrm{N} ., 2^{\circ} 4 \mathrm{I}^{\prime} \mathrm{E}$.

$50^{\circ} 46^{\prime}$ N., I $34^{\prime}$ E.

$50^{\circ} 36^{\prime}$ N., $0^{\circ} 03, \mathrm{~W}$

$50^{\circ} 2 \mathrm{I}^{\prime}$ N., $0^{\circ} 34^{\prime}$ W.

$49^{\circ} 45^{\prime}$ N., I $\mathrm{I}^{\circ}$ W. Hous

$50^{\circ} 23^{\prime}, \mathrm{N} ., \mathrm{I}^{\circ} 5 \mathrm{I}^{\prime} \mathrm{W}$.

$50^{\circ} \mathrm{I}^{\prime} \mathrm{N} ., \mathrm{I}^{\circ} 33^{\prime} \mathrm{W}$.

$50^{\circ} 07^{\prime}$ N., $2^{\circ} 21^{\prime}$ W.

$50^{\circ} 04^{\prime}$, N., $4^{\circ} 22^{\prime}$ W.

政

$49^{\circ} 47^{\prime}$ N., $2^{\circ}$ or' W.

$50^{\circ} \mathrm{II}^{\prime} \mathrm{N}$., I $\mathrm{I}^{\circ} 33^{\prime} \mathrm{W}$.

$\therefore$

$4980^{*}$

$4980^{*}$
$2468 *$

$1980^{*}$

9

$8680^{*}$

$480^{\star}$

440 *

$800^{\star}$

$600^{*}$

$260^{\star}$

$660^{\star}$

800 *

62

479 (2I)

29 (54)

$\because$ (10)

$\begin{array}{ll}\cdots & 128 \\ \cdots & \text { I68 }\end{array}$

$\begin{array}{lr}\ldots & 168 \\ \ldots & 72\end{array}$

.. 23

(2)

i (8)

$3(7)$

$\begin{array}{cc}207(\mathrm{I}) & 96(2 \mathrm{I}) \\ 1000^{\star} & 6 \mathrm{I}(\mathrm{II}) \\ 500^{\star} & 93(37) \\ 10 & \cdots \\ 13 & \cdots \\ 1 & \cdots\end{array}$

.

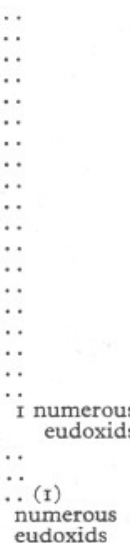

numerous

+ The writer is indebted to Mr A. C. Simpson, Fisheries Laboratory, Lowestoft, for the counts of pilchard eggs from these two stations.

$\neq$ Catches not examined for mackerel eggs and Sagitta spp. 


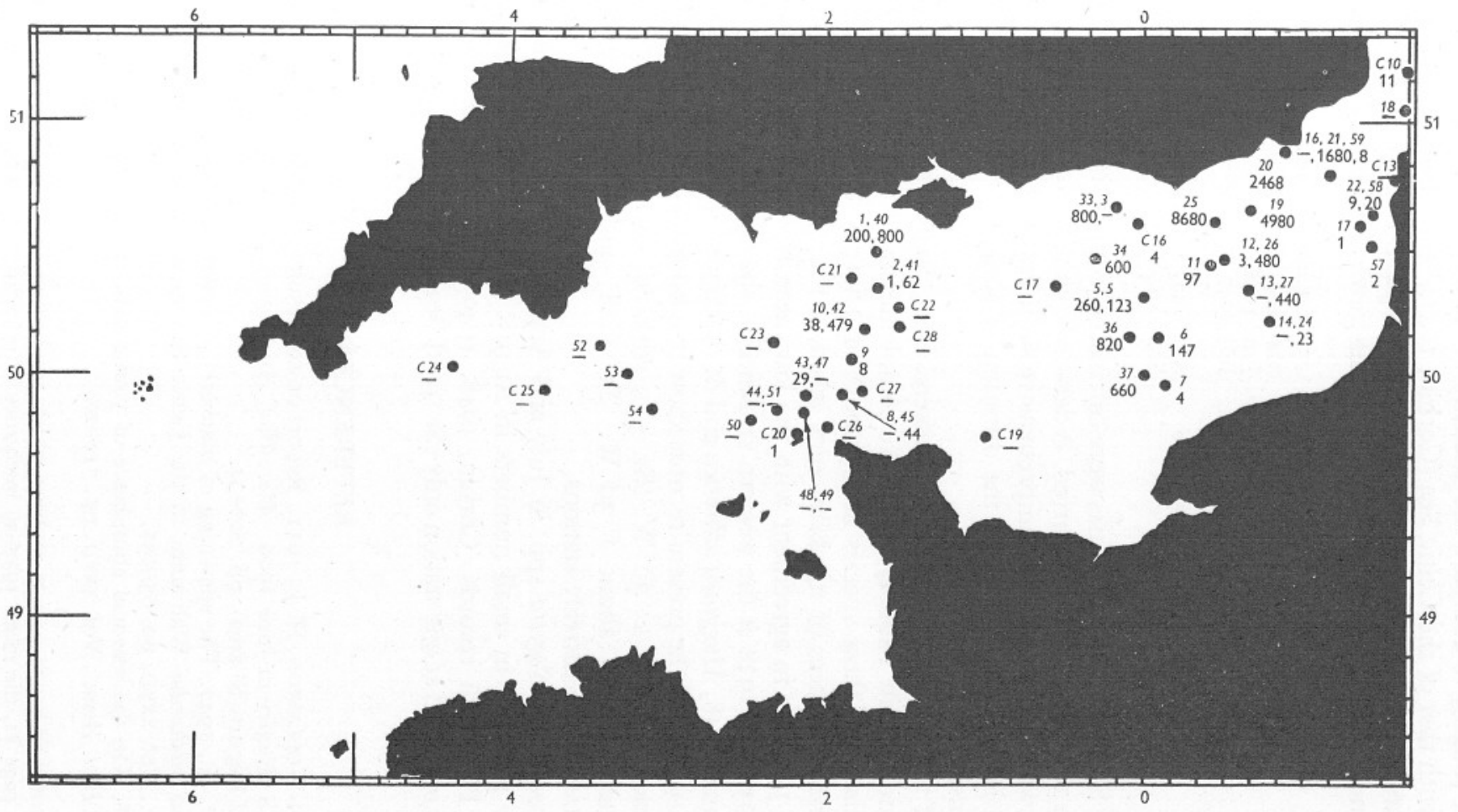

Fig. I. Records of pilchard spawning in the English Channel in 1947 and I948. Station numbers are shown in italics. The lower figures are the numbers of pilchard eggs per haul. Stations worked by the Colleen have the prefix $C$; those worked by the Manihine have no prefix. Several of the stations which were close together have for convenience been indicated by a single point on this chart. 
In order roughly to compare the intensity of spawning in the central English Channel with that of the Celtic Sea (Corbin, I947), ${ }^{1}$ the means of the present records have been multiplied by four (figures in parentheses) to approximate the $\mathrm{I} \mathrm{m}$. net catches to those of the $2 \mathrm{~m}$. ring-trawl. It should be noted that

\begin{tabular}{|c|c|c|c|c|c|}
\hline \multicolumn{3}{|c|}{ Western stations } & \multicolumn{3}{|c|}{ Eastern stations } \\
\hline & & & $\begin{array}{l}\text { May I948 } \\
\text { June I948 }\end{array}$ & $\begin{array}{r}2379 \\
628\end{array}$ & $\begin{array}{l}(9516) \\
(2512)\end{array}$ \\
\hline $\begin{array}{l}\text { July } \text { I947 } \\
\text { July I } 948\end{array}$ & $\begin{array}{r}61 \\
236\end{array}$ & (244) & July I947 & 68 & $(272)$ \\
\hline Aug. 1948 & Nil & & Aug. 1947 & I4 & \\
\hline Sept. 1948 & Nil & & Sept. I 948 & Io & \\
\hline
\end{tabular}

the Celtic Sea spawning intensities were calculated from positive stations where more than roo eggs per haul occurred. A detailed quantitative comparison of the two areas would require more comprehensive sampling in the English Channel. It should be further noted that the duration of some of the Manihine hauls varied considerably.

Data of the numbers per haul of mackerel eggs, Sagitta spp. and Muggiaea spp. are included in Table I, as they are complementary to the observations on the abundance of these species in Plymouth off-shore waters.

The small numbers of mackerel eggs taken in the central Channel in July I947 and I948 are in agreement with the low intensity of spawning observed in July I937 and I938 at the western entrance of the Channel (Corbin, I947).

In autumn I948, Muggiaea atlantica and M. kochi were plentiful off Plymouth (Corbin, I949), and the present records show that both species were distributed up Channel to about $2^{\circ} 30^{\prime} \mathrm{W}$. (St. 5I), with M. kochi extending slightly farther eastwards to about $\mathrm{I}^{\circ} 3 \mathrm{O}^{\prime} \mathrm{W}$. (St. C28) and also out-numbering $M$. atlantica at the easterly stations.

The absence of Sagitta spp. in July and August, I947, in May-July I948, and their presence in small numbers in August and September I948, agrees with the Plymouth records (Corbin, I948, I949). In the eastern Channel, S. elegans occurred at one station only (St. 3, off Beachy Head, three specimens).

\section{REFERENCES}

Buchanan-Wollaston, H. J., I9II. Report on the results of the fish-egg cruise made by S.S. Huxley in June 1909. Mar. Biol. Association, International Investigations, Third Report (S. area), pp. 207-34.

Corbin, P. G., I947. The spawning of mackerel, Scomber scombrus L., and pilchard, Clupea pilchardus Walbaum, in the Celtic Sea in 1937-39. fourn. Mar. Biol. Assoc., Vol. xxvir, pp. 65-I32.

- 1948. On the seasonal abundance of young fish. IX. The year 1947. Fourn. Mar. Biol. Assoc., Vol. xxviI, pp. 718-22.

1 The writer wishes to correct an error which occurred in this paper. In the last line of Table III, page $8 \mathrm{I}$, the mean $1937-39$ intensities of pilchard spawning should be amended to read: April 6680, May-June I4,843, July 470 I. 
Corbin, P. G., I949. On the seasonal abundance of young fish. X. The year 1948 . Fourn. Mar. Biol. Assoc., Vol. xxvin, pp. 707-I2.

FuRnestin, J., I939a. Observations diverses sur la ponte de la plie (Pleuronectes platessa Linné), de l'équille (Ammodytes tobianus Linné) au Sandettié et sur la présence de la sardine (Clupea pilchardus Walbaum) et l'extension de son aire de ponte en Mer du Nord et en Manche. Cons. Int. Explor. Mer, Rapp. Proc. Verb., Vol. CXI, pp. 4I-54.

- I939b. Recherches sur le maquereau en Mer Celtique. Cons. Int. Explor. Mer, Rapp. Proc. Verb., Vol. cxI, pp. I9-36.

— 1945. Contribution à l'étude biologique de la sardine atlantique (Sardina pilchardus Walbaum). Rev. Trav. Off. Pêches Marit., I939-43, T. xIII, Fasc. I-4, pp. $22 \mathrm{I}-386$.

GalL, M. H. W., I949. Measurements to determine extinction coefficients and temperature gradients in the North Sea and English Channel. Fourn. Mar. Biol. Assoc., Vol. xxviII, pp. 757-80. 